\title{
Twists of Democracy in the Ukraine, or the Political Instability of the Country Reconsidered
}

\begin{abstract}
When it comes to a description of the political process in Ukraine, scientific literature often employs the concept of political instability or better still, that of the instability of a political regime. To quote the scientific community, there are two key factors underlying the political stability/instability of the country, these include: features of 'political competition' among key political forces and the nature of functioning of the top level executive branch in the political system. This paper relies on criteria suggested by Jack Golsdtone and Jay Ulfelder, both American investigators, and discusses the dynamic character of the political regime in Ukraine in the aftermath of the Orange revolution. The analysis is based on the following key assumption, i.e. that political instability will for long be inherent to a democratic regime in Ukraine.
\end{abstract}

\section{Introduction}

Issues surrounding the political regime establishment in Ukraine, or, which is more acceptable by political science, those of its consolidation, are discussed often and widely. The political events in the late 2004 and early 2005 are often referred to as the Orange revolution in literature and are both scientific and popular. These served as a catalyser to start new investigations. A considerable proportion of investigators and political observers considered the revolution an upheaval and impulse not only to turn the foreign policy in Ukraine towards one more favourable to the West, but also to facilitate the development of a more transparent, democratic model of a political system, rather like one which is Central European. ${ }^{1}$ In this context, the so-called constitutional reform deserves a largely positive evaluation; one can count its formal functioning since the early 2006, and granted more powers to the Parliament (the Supreme Rada). This is how Ukraine was supposed to turn from a presi-

\footnotetext{
* Dr. Vladas Sirutavičius is an associate professor of the Institute of International Relations and Political Science, University of Vilnius. Address: Vokiečių 10, LT-01130 Vilnius, Lithuania, tel. +370 526268 43, e-mail: vsir@takas.lt

${ }^{1}$ Moshes A., "Ukraine: Domestic Changes and Foreign Policy Reconfiguration", Political Trends in the Eastern Europe: Ukraine and Belarus (ed. By V. Silitski and A. Moshes), 2007, p.17, www.StrategicStudiesInstitute.army.mil
} 
dential republic to parliamentary - presidential one. In fact, one must point out that 'constitutional reform' reflected interim political compromise achieved in the climax of the revolutionary events between two fighting groups of political elite, i.e. the 'orange' one, headed by Yushchenko and Tymoshenko, as well as the 'blue white' one, headed by Yanukovych, rather than a clear, well thought through plan, on the way to reform political system of the country.

We would be inclined to think that, in general, the definition of instability comes to mind when it comes to the charactering of the dynamics of a political process in Ukraine in the aftermath of Orange revolution. There were several facts pointing to the political instability in the country, firstly, those that came victorious in the Orange revolution failed to consolidate their victory. The conflict between President Yushchenko and Prime Minister Tymoshenko turned out in the resignation of the latter in the middle of 2005. Secondly, compromises reached between Yushchenko and Yanukovych proved to be short-term. Although the political agreement between the two leaders and political forces they headed did facilitate, after considerable trouble, a new orange government headed by Yekhanurov, yet the stable work escaped its grasp. Thus the Rada election was organised in March 2006. Thirdly, although the orange block did formally win the election, however, its leaders failed to form a stable majority and reach an understanding on the distribution of key political positions. When the socialists headed by Moroz merged with the Party of Regions headed by Yanukovych, the latter took the office of the Prime Minister. Fourthly, with confrontation between the majority in the Rada and the Government from one side and the President from the other deepening, Yushchenko decided to dissolve the Parliament and to announce premature election. Fifthly, the premature election did not substantially change the relation of political forces in the country. Not only did it highlight the trend of two confronting political forces, the Party of Regions headed by Yanukovych, mostly supported by the population in the southern and eastern regions of the country, and block headed by Tymoshenko, supported by the central and western regions, dominating the political map of Ukraine. However, neither of the said political forces commands the majority in the Rada and is compelled to look for allies if it is to form the Government.

We have employed the definition of political instability or, to be more precise, that of instability of political regime in order to characterise the political process in Ukraine. It well deserves a little more attention. Modern investigations, having the key object of analysis structural political crises and state failure, also employ concept of political instability. ${ }^{2}$ To quote the scientific community, there are two key factors underlying political stability/instability

\footnotetext{
${ }^{2}$ A study by a group of US scientists serves a good example; it deals with cases, reasons and consequences of failures of states 1955 - 2006, "Political Instability Task Force. Internal Wars and Failures of Governance" (PITF). The study was launched in 1994, and was sponsored by the US Government. Key objective of the study was to learn "the reasons behind the vulnerability of states, ranging from political instability to failure of states". The study material is available at: http:/www.cidcm.umd.edu/projects/ project.asp?id=19
} 
of the country: features of 'political competition' among key political forces and nature of functioning of top level executive branch in the political system. Therefore, 'closed autocracies', where any chance for political competition for power is in fact virtually eliminated, and there are in fact no state institutions restricting top executive branch, may be deemed stable political regimes. Liberal democracies, or political regimes with 'open political parties' competing, and minimum likeliness of coercion also prove stable. What is also important in these regimes is that executive branch is 'largely restricted' by independent courts of law and the legislative branch. ${ }^{3}$

According to Jack Golsdtone and Jay Ulfelder, it is those regimes that can be characterised as 'nominally' formally democratic, yet where political competition, that between dominant political forces is characterised by factionalized political competition and where the executive branch clearly plays the dominant role are among those most vulnerable and unstable. The model of factionalized political competition is characterised by three key traits: polarization, parochialism and mobilisation. Parochialism characterises a certain model of political competition, where key political parties express interests of narrow social or economic groups by favouring them in one way or another. Such political parties do no perform mediator (key) function between various social groups; rather, they strive to highlight their differences. Polarization happens when competition between key political forces for the influence on political centre becomes 'game' where nobody wins. Not only does the losing party lose political positions; it also faces economic pressure and political prosecution. Lastly, the competing political forces, with view to implement their 'parochial' interests recourse to collective actions, mobilisation of their supporters which can at times include coercive character. ${ }^{4}$

The institutional structure of the political system with the dominant role played by top executive branch, barely restricted by other public institutions and controlled, poses a danger to the political stability due to two major reasons. First, those once elected in such power, and representing the same, may seek to further increase limits of one's competence, and, what's important, to retain it infinitely. Such a situation may provoke either an introduction of dictatorship or split of the society. On the other hand, in the case of the political system, characterised also by an opposed political competition, top executive branch becomes key political 'prizes.' The political power, winning it successfully, may expect not only to fully satisfy the interests of its supporting groups, but to eliminate its opponents from the political game also. It thus makes political compromise considerably less likely, and the confrontation more probable ${ }^{5}$ (more diffuse systems, where top executive branch lacks influence, provides more favourable preconditions for political powers seeking compromise and 'distribution' of power).

\footnotetext{
${ }^{3}$ Goldstone J., Ulfelder J., "How to Construct Stable Democracies" The Washington Quarterly, vol.28, Winter 2004/2005, p.9-20. As a matter of fact, both authors of the paper participated in the project.

${ }^{4}$ Ibidem, p. 15 .

${ }^{5}$ Goldstone, Ulfelder (see footnote 3) p.16-17.
} 
One should point out that the issue of instability of the democracy in Ukraine, taken from one aspect or another, has pretty frequently become an object of study by scientists, including Lithuanian scientists. We have no intention to go into much detail here. There are, however, but a few studies that we shall review, thereby concentrating on issues of methodological character. A group of authors (V. Pigenko, Ch. R. Wise and T. L. Brown), discussing the issue of democratic stability in Ukraine, and to get more specific - the position taken by the political elite of the country on the matter of separation of powers (legislative and executive branch) have observed that political discussions on the structure of institutional system has come under strong influence of different ideological provisions and different geopolitical orientation. ${ }^{6}$ In the eve of passing Constitution of 1996, political groups supportive of idea of strong parliament, also sought preservation of fundamentals of socialist - planning economy and for most productive development of relations with Russia. Yet those in favour of a strong presidential power supported the in-depth market reforms and one more favourable to the West. The first trend was more characteristic to political left in Ukraine (socialists and communists) and the second to the right, or the so-called national-democrats. According to the authors of the study, it is the incompatibility of ideological and geopolitical orientations that makes agreements on institutional construction among the political elite unstable, promises new conflicts, even more so, where the winner takes steps to change the rules of institutional 'game.' Ž. Šatūniene, a Lithuanian investigator, who analysed preconditions for establishment of stable, consolidated democracy in Ukraine, has drawn a general conclusion that "instability of political regime (democracy and authoritarianism alike)" is 'normal' and long-term, therefore, arguably, a consolidated form of political regime in the post-Soviet Ukraine. ${ }^{7}$ Key arguments that the author employs to draw the above conclusion include that, given particular merging character of business and political groups interests, structure of political elite in Ukraine will be dominated by an 'oligarchic' group, the latter seeking to maximise its benefits, the said situation inducing stress and controversies, which can only lead to instability of political system.

We would be inclined to think that both of the above studies may prove to be useful in that they bring additional arguments to support model of 'opposed political competition'. This text shall therefore, on the basis of criteria the suggested by Jack Golsdtone and Jay Ulfelder, consider the dynamics of the political regime in the Ukraine in the aftermath of the Orange revolution. The key assumption in the analysis lies upon the assumption that political instability will be inherent to democratic regime in Ukraine for considerable period of time.

\footnotetext{
${ }^{6}$ Pigenko V., Wise Ch., Brown T. L., "Elite Attitudes and Democratic Stability: Analysing Legislators' Attitudes towards the Separation of Powers in Ukraine", Europe - Asia Studies, vol.54, no.1, 2002, p.92. 7 Šatūnienẻ Ž., "Nepastovus posovietinès Ukrainos politinis režimas ir demokratijos konsolidavimo perspektyvos", Politologija, no.1, 2006, p.62-63.
} 


\section{The Character of Political Competition}

Thus, why is the model of political competition inherent to Ukraine? With the March 2006 Rada election drawing closer, three key political forces emerged in political - party system, including pro-presidential, or the party in power, to put it more precisely the coalition of several parties; Our Ukraine, headed by President Yushchenko; Party of Regions headed by its leader Yanukovych and Yuliya Tymoshenko (when the so-called 'orange' forces split in the autumn of 2005, it finally became obvious that parties headed by Tymoshenko and Yushchenko shall run the election independently).

Some analysts in Ukraine have claimed that even before the 2006 Rada election an ever increasing "public - political split, taken place as early as during presidential election" may pose a key challenge and threat to the political system and its stability. Sociological studies (spring 2005) showed that a considerable portion of the Ukrainian population records the split of the character. According to the surveys, approximately $44 \%$ of the Ukrainian population claimed such a split did exist in the country and $40 \%$ of respondents denied that. As much as $82 \%$ of the electors supporting Yushchenko in the presidential election claimed that the country was "on the right path", however, only $17 \%$ of those voting in favour of Yanukovych concurred with the same. ${ }^{8}$ No doubt, one can think that the very conception of 'split' in the society was firstly influenced by the presidential election campaign, which was still not such distant of a memory. Yet one must also point to the fact that later surveys also evidenced an existence of certain stress in the society, to be more specific, on the country scale between the East and the West. A survey by the International institute of Sociology in Kiev in the late 2005 (November) found that $35 \%$ of the respondents approved of the statement referring to the stress between the East and the West, and 49\% disapproved of the same statement (as a matter of fact, as much as $54 \%$ of the population in the eastern regions of the Ukraine approved of the statement, and on the contrary, in the western ones, the majority disapproved of the same). ${ }^{9}$ Geopolitical views of the population in the given regions in the Ukraine also displayed obvious differences. The surveys in 2005 evidenced an unequivocal support of the development of European Union relations (being 60.7\%), and $7.9 \%$ and $6.6 \%$ of respondents supported eastern vector, or relations with Russia and CIS respectively, to be taken by the foreign policy. Eastern Ukraine was, on the contrary, clearly dominated by totally opposite trends. Here, $56.7 \%$ and $16.2 \%$ of the respondents considered relations with Russia and CIS countries a

\footnotetext{
8 Якименко Ю., Литвиненко А., Жданов И., “Кто и за что, с кем и против кого? Партии Украины за год до выборов", http://www.zn.ua, 0204 2005. According to the pools at the end of 200550 percent of ukrainians considered that their living conditions after Jushchenko became the president deteriorated and only 11.5 percent argued that it became better. See "Почти половина украйнцев щитает, что при Ющенко они стали жить хуже”, www.rosbalt.ru, 20102005.

${ }^{9}$ Moshes (see footnote 1) p. 22 .
} 
priority, and $16.8 \%{ }^{10 *}$ of the respondents supported the development relations with the European Union. (Geopolitical orientations differed in case of Southern and Central regions also. The former preferred 'eastern' orientation, and the latter favoured 'western' one. However, gaps did not prove so significant in this case)..$^{11}$

Some analysts in the Ukraine have claimed, even before the election, that the 2006 Rada election would do nothing but increase the existing regional - cultural divides. Political parties, with view to mobilise their 'own' electors, may well take steps to exploit the existing cultural - regional differences and controversies. Yet the escalation of regional and cultural differences (e.g. matter of Russian as official language, which is relevant to the East but not so in case of the West) in the course of election campaign could do no more than increase the splitting of the country along the eastern and western divide. There were also those who thought 'conflict topics' will basically dominate the election, which will make relations between key political parties in the Ukraine even more complicated. There were speculations that the representatives of 'orange' camp will take steps to 'discover' various crimes of the former regime, will escalate the topic of the fight against oligarchy, and various corrupt politicians. Opposition, the 'blue' ones, should exploit the matter of 'political repressions', both in regard to individuals and specific regions that supported opposition during the presidential election. Another possibility, not to be excluded, is that those in favour of regionalism may well use matter of status of Russian as second official language during the election campaign as well as the necessity to develop better relations with Russia not excluding even the escalation of anti-western or anti-American sentiments. ${ }^{12}$ Hostility, displayed publicly, between the political forces during the election, should have an impact on the likeliness to form post-election political compromises. Even more so, that most pre-election forecasts witnessed that no political force will manage to bring an absolute victory and will be compelled to look for allies.

One should note that by far all speculations of scientists regarding the course of election have been proven correct. The results of the election evidenced an increasingly structuralised character the political - party system that

\footnotetext{
10* A decrease in support of 'polyvectoral character' also known as balancing between the West and East policy was also noticeable. (see Евгений Головаха: “Борбу между “правыми” и “левыми” некомпетентные политики превратили в войну между региональными и языковыми групами”, , http://www.grani.kiev.ua, 200608 06.) And as late as in 2003 'polyvectoral character' was supported by $38 \%$ of population in the Eastern and Southern regions (7\% supported the 'western' course and 22\% supported 'eastern' one, respectively), 39\% - central (in this case, $11 \%$ of population supported the 'western' course and 13\% supported the 'eastern' one respectively), $20 \%$ supported the 'western' one ('pro-western' orientation appeared most popular, at 39\%, whereas the 'eastern' vector was supported by $5 \%$ ). See Konieczna J., "Mędzy Wschodem i Zachodem”, Fundacja Batoriego, Warszawa, 2004, p. 8-9.

${ }^{11}$ From "Ukraine's European Integration in Popular Perceptions", National Security and Defence, no.7, 2005, p.43-44.

12 Якименко Ю., Литвиненко А., Жданов И., “Кто и за что, с кем и против кого? Партии Украины за год до выборов”, http://www.zn.ua, 02042005.
} 
Ukraine is acquiring. The Party of Regions headed by Yanukovych appeared the most successful at the election, having scored little more than $32 \%$ of elector votes and taking 186 seats in the Parliament. The block of Tymoshenko (22.27\% and 129 seats) and the Our Ukraine block, supported by President Yushchenko only came third (13.94\% and 81 seats). Socialist party $(5.67 \%$ and 33 seats) and Communist parties (3.66\% and 21 seats) also passed the threepercent barrier. The above election results and the relation of political forces in the new Rada evidenced that the 'orange forces' (the Tymoshenko block, Our Ukraine and the socialists headed by Moroz) are in a very favourable position to form a sufficiently stable majority coalition in the Parliament that, pursuant to the new Constitution, shall submit candidate to take the position of Prime Minister to the President. Some analysts, evaluating the good performance by the Tymoshenko block, have come up with conclusion that, overall, there are preconditions forming in Ukraine for the new, 'Centre' political block (political party by Tymoshenko has been most successful in the central regions of the country). And this is the block to reduce the tension existing between the East and central-western region. ${ }^{13}$ However, one should also note in this respect that, in our opinion, it was her political charisma, essentially populist promises and ultimately, the 'radical' opposition posture by her party, rather than her political program, having its objective to 'unite' the country that ensured good results to the block of Tymoshenko (following the 2005 Autumn election, Tymoshenko has retreated to the opposition of President Yushchenko, taking opportunity to express some pointed criticism with regard to the 'oligarchic' Party of Regions).

On the other hand, one should still observe that certain of predictions of the political scientists did appear correct. Experts in the policy of Ukraine, when summarizing the 2006 Rada election, have come to conclusion that traditional political divides, inherent to political system in Ukraine (left and right, national - democrats - Russophiles) is weakening, yet the divide between the East and West remains relevant. ${ }^{14}$ What was usually stated when supporting the above finding was that the electorate would usually be mobilised on a regional linguistic, or, to rephrase it, on territorial - cultural basis. The election results largely confirmed the said findings..$^{15}$ The Party of Regions was successful in ten southern and eastern regions of the country (the party headed by Yanukovych was most supported and was successful with highest ration in the areas of Doneck, Luhansk and the city of Sevastopol). A total of over 8.1 million

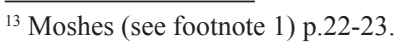

14 “Евгений Головаха: “Борбу между “правыми” и “левыми” некомпетентные политики превратили в войну между региональными и языковыми групами”, http://www.grani.kiev.ua, 06082006.

${ }^{15}$ See: http://www.cvk.gov.ua/vnd2006/w6p001.html
} 
electors voted for the Party of Regions $s^{16^{*}}$. Block headed by Mrs. Tymoshenko was successful in 14 areas that investigators attribute to the central part of the country. A total of over 5.6 million electors voted for the party headed by Mrs. Tymoshenko. This political force scored the most votes in the areas of Kiev and Volyn and Kiev, the capital city of the country. Our Ukraine, headed by President Yushchenko, was successful in barely three western areas of the country: Ivano-Frankivsk, Lvov and Carpathian - Ukraine (a little more than 3.5 million electors supported the pro-presidential party). Such regional - cultural split of the electorate and party system impeded the way to political compromise, and rendered possible political coalitions unstable and short-term.

It is important to note yet another aspect of political - party system. The divides existed not only between the 'orange' political forces and the 'blue' ones, the Party of Regions, but inside the so-called democratic coalition itself. In general, the 'orange' camp in terms of political ideology consisted of forces exhibiting considerably variety, and ranging from socialists to national democrats. Even one can claim that these forces were united by the legacy of the 'Orange' revolution, including the reach for democratisation of political system and reforms, yet, when it came to contents of specific reforms, they envisaged it differently and often to the contrary. The priorities for the foreign policy and geopolitical orientation, too, were far from uniform. Now in order to keep the said coalition united, the matter of its leader and his authority gains importance. President Yushchenko could well be considered an informal leader of democratic coalition. However, by March 2006 he could no longer be the leader and mediator, coordinating the interests of all orange forces. We would be inclined to think that this was due to several reasons. First, the ratings of the President of Ukraine appeared to be on a persistent decline in the aftermath of the revolution (the fall in popularity of Yushchenko is noticeable already in the early 2005, followed by simultaneous rise of Tymoshenko ratings. To rely on the data produced by surveys, the rating of Yushchenko decreased $37.5 \%$ to $20 \%$ February to June 2005, and that Tymoshenko rose $10 \%$ to $17.3 \%) .{ }^{17}$ Thus Yushchenko acquired a strong competitor in the orange camp. It was Tymoshenko, her party, as we have observed before, that came

\footnotetext{
${ }^{16^{*}}$ There are, however, scholars claiming that 'political subjectivity' of eastern Ukraine is well exaggerated. They base such presumption on the conduct of political elite in the eastern Ukraine in the aftermath of the Orange revolution. At least part of political elite in the eastern Ukraine sought compromise with the new 'orange' government (some politicians and members of business elite, who once were active in the Party of Regions took the side of the 'orange camp'). Such posture was influenced by the fact that big business appears the key political subject in the east of the country and it is inclined to seek 'constructive' dialogue with any power in general. This served as a basis for conclusion that it can not possibly make serious political opposition. See also “Доклад Института национальной стратегии Украины (C. Белковский, К. Бондаренко, В. Вакарюк, Е. Курмашов, А. Мушак). Новый политический сезон: выборы-2006 и продолжение оранжевой революции“, Агентство политических новостей, http:// www.apn.ru, 24082005.

${ }^{17}$ Sеe Доклад Института национальной стратегии Украины (С. Белковский, К. Бондаренко, В. Вакарюк, Е. Курмашов, А. Мушак) „Новый политический сезон: выборы-2006 и продолжение оранжевой революции“, Агентство политических новостей, http://www.apn.ru, 24082005.
} 
second in the election, and the coalition of parties, Our Ukraine, headed by President Yushchenko came in third. In general, Tymoshenko has positioned herself as an active advocate of interests of 'ordinary people', fighting against the oligarchs and evil intentions of Russia. Finally, the constitutional reform on its way since early 2006 has restricted and also, in view of key political actors, has weakened the powers of the President. On the same time the prestige and influence of the Chairman of the Rada and the Prime Minister increased. This fact in the 'orange' camp increased competition and rivalry even more, as to who should claim them. Tymoshenko appeared as the most tangible aspirant to claim the position of the Prime Minister, however, such a course of events, naturally, was not really popular with the President.

Just to remind ourselves of the disagreements between the leaders of the Orange revolution political structures supporting the same are traceable back to mid 2005, ${ }^{18}$ and in September Yushchenko and Tymoshenko union saw its final collapse. The crisis formally originated with advocates of Tymoshenko accusing politicians close to President Yushchenko of corruption. The President decided and removed the Government headed by Tymoshenko and parted with some of his political comrades. The political block headed by Tymoshenko thus moved to opposing the President. This in turn did nothing but deepen the political crisis in the country. The Rada did not approve of the Yury Jechanurov as new head of Government until this candidate was supported by the Party of Regions headed by Yanukovych. Yushchenko, with view to get away from political crisis and for the government signed an agreement with Yanukovych whereby the new power undertook an obligation to refrain from prosecuting advocates of Yanukovych. Such a pact allowed for the formation of the government and also a stabilised situation in the country for the interim period. On the other hand, such inevitable political compromises primarily among the electorate of the orange induced disappointment and increased stress and conflicts in the democratic camp. In general, Tymoshenko took steps to exploit compromising character of President and the Government, whether pretending or genuine, and presented herself as politician who did not know compromise. She was among those who criticised the late 2005 agreement between Gazprom, Russian gas monopolist and Ukraine which was supported by the President and the Prime Minister. As a matter of fact one would note that this agreement was evaluated as not transparent, however it was Tymoshenko who made the cancellation or at least review of the agreement the objective of her policy. Given such a situation full of mistrust and even hostility, the issue of forming the orange coalition became very serious. The events that followed after 2006 election totally confirmed the presumption. Negotiations regarding the formation of coalition ran on. The leaders of the 'orange' ones failed to agree upon the key official positions. The negotiations were further hampered by the

\footnotetext{
${ }^{18}$ Political analysts have noted that key actors of the 'orange' camp, as early as in summer 2005 no longer concealed mutual hostility and demonstrated mutual conflicts publicly. Доклад Института национальной стратегии Украины (Ibidem.)
} 
fact that Tymoshenko wanted to retain the position of Prime Minister to herself and there were political forces strong enough to prevent Tymoshenko from getting the position. Finally the efforts to form the 'orange coalition' proved unsuccessful with the retirement by the socialists.

The formation of new 'anticrisis' coalition, including Party of Regions, socialists and communists was announced immediately. This coalition elected Moroz and submitted the candidate of Yanukovych to the position of Prime Minister. Political crisis which originated following March Rada election were settled in the earlier August only. President Yushchenko submitted Yanukovych for approval as the Prime Minister. New coalition (Party of Regions, Our Ukraine, and socialist party) was formed in the Rada; it also formed the Government. Party of Regions took the block of economical ministries and the President retained influence when forming country's security and defence policy. The members of the coalition signed document initiated by the President, defining interior and foreign policy priorities in Ukraine (true, the document was void of legislative power and imposed no obligations on the signatories. It was not signed by the representatives of Tymoshenko block). The Constitutional Court was finally formed as the result of the agreement. As evidenced by the further course of events, the political compromise between the party in power and the President, was interim only.

The analysts, as early as the summer of 2006 began reporting of an inevitable crisis between the two branches of executive powers, the President and the Cabinet. ${ }^{19}$ Initially, the conflicts between Yushchenko and Yanukovych appeared to be due to several ministers (foreign affairs and defence). According to the quota of the President established in the Constitution, the latter was entitled to appoint several ministers to the Government. The conflict between the two representatives of power, the President and the Prime Minister was largely due to the establishment of competence limits. The Prime Minister appealed to the reform on the way and took steps to expand the limits of his competence and the President, again appealing to the reform to retain the same. The relationship between the President and the Prime Minister were further complicated by the Law on Cabinet adopted by the Rada in January 2007. Such an enactment was provided pursuant to the constitutional reform on the way. On the other hand, it was the Rada that adopted the Law on cabinet drafted by the Party of Regions, which further expanded the functions of Prime Minister and thereby decreased the competence of the President. Such wording of the law was vetoed by the President; however the veto was overruled by the Party of Regions and the block of Yulia Tymoshenko which supported the same. ${ }^{20}$ In general, it is up to Constitutional Court to arbitrate the balancing political system; however, it was practically eliminated from settling political disputes in Ukraine. ${ }^{21}$

The race for power between the President and Prime Minister as well as

\footnotetext{
19 “Эксперты: “Оранжевые” министры не сработаются с Януковичем”, www.Korrespondent.net 2208 2006.

${ }^{20}$ On Cabinet Law see Ведерникова И., “Кабмин в законе”, http:/www.zerkalo-nedeli.com/op/ show/612/54393/, no. 33, $02-08092006$.

21 "Will democracy survive in Ukraine? What the experts say", http://www.icps.com.ua, 12022007.
} 
the majority in the Rada supporting him further accelerated. The President demanded the Rada to pass a new Law on the Cabinet as amended, which would take into account the remarks made by President, to prevent the movement of deputies from one party to another and for that matter, to pass Law on Imperative Mandate for the Rada deputies. ${ }^{22 *}$ The majority in the Rada, supporting the Prime Minister was not very swift to comply with the demand by the President. It seems that ideas to form constitutional majority in the Rada and to announce impeachment for the President were increasingly stronger. The confrontation reached its peak in the spring of 2007. President Yushchenko saw that coalition in power did not abandon the idea to form constitutional majority in the parliament claimed to be ready to pass a resolution regarding removal of Rada and organising of premature election (among those especially in favour of Rada and premature election was Tymoshenko). The Rada was removed in the early April and a new parliamentary election was scheduled. One should point out that the road to election was by no means simple. The period from spring to the autumn of 2007 when in October election to the Rada was arranged, was very tense. Politics in Ukraine during that period was characterised by a confrontation between the legislative and executive branch (President), between the Government and the President, between various state officials, political parties and specific politicians; furthermore, the efforts of key political forces mobilised their advocates to take collective action. There appeared tents in the capital city of the country and people were brought to meetings from various regions. However, no outbreak of violence occurred.

\section{The 2007 Rada Election: To Reconciliation or a Bigger Confrontation?}

The 2007 Rada election was formally won by the party of regions, having collected $2 \%$ more of the elector's votes, than in 2006 . However, if we compare absolute numbers we observe that the support by the electors to the Party of Regions decreased a little: in 2006 it collected 8,148,745 votes of electors and in $2007-8,013,918$. On the other hand, one should observe that the party retained the primary position in traditional eastern and southern areas of Ukraine. Furthermore, those in favour of Region party were successful in slightly increasing the number of the advocates in central and even western part of Ukraine (in general, those in favour of the Region party intended to score a 5\% to $10 \%$ increase in number of electors. Yet such numbers were not provided in all

\footnotetext{
${ }^{22^{*}}$ As a matter of fact, the Law on Imperative Mandate was critically evaluated by the experts of European Council. The Venice committee stated that European democratic states rely exclusively upon idea of free mandate of national representative. According to some politicians in Ukraine, imperative mandate should discourage deputies from changing political groups. In this case deputy forfeits his mandate when he changes his political group (by the way, practice of imperative mandate does exist in India, Nigeria, South Africa, Cuba, and Vietnam).
} 
areas). It is also worthy to mention that the support for the Party of Regions was most reduced in the southern regions of the country, where the party lost 130.6 thousand votes in Doneck, 70.6 thousand in Luhansk, 106.5 thousand in Charkov. It is due to the above results that the Party of Regions scored fewer seats in the Rada, 175 in stead of $185 .{ }^{23}$

The block by Tymoshenko received 30.7\% elector votes, and thereby increased the ranks of its supporters by 1.5 million (in 2006, the block received 5,652,876 and in 2007, 7,162,174 electors). In 2007 the Rada election Tymoshenko party was successful in 16 areas (in 2006, victory came in 14 areas). In 2007, the party Tymoshenko block was successful in Ivano - Frankivsk and Lvov areas (in 2006, these where the areas that brought success to the alliance of parties Our Ukraine). In general, political analysts observe that Tymoshenko block was in fact a little more successful in scoring votes across all areas of Ukraine than in the previous election. However, it was the western areas of the country, including those of Ivano - Frankivsk, Lvov, Rivno, Ternopol that most contributed to the Tymoshenko. In case of the above areas, by comparison with results for 2006, 15-20\% of 'additional' elector's votes were collected (largely on account of Our Ukraine party). Just like in case of previous election, the southern and eastern regions posed most challenging to Tymoshenko (in Krym, Doneck, and Luhansk).

The coalition of Our Ukraine, National Self-defence, collected 3.3 million elector votes, which means that political power actively supported by the President collected 238 thousand votes less than in the previous election. Only one area was successful, the Carpathian Ukraine. The indicators of block went down in 12 areas. However, like in former Rada election, the 'orange' forces combined collected more votes than the Party of Regions. Keeping in mind the fact that socialists headed by Moroz did not make it to the Rada, the 'orange' coalition has at least formally better chances to submit candidate for the Prime Minister.

Such results of the election allow for several findings. First, we would be inclined to think that regionalism does perform and will continue to perform important role in the politics of Ukraine. The course and result of the national election (President and Parliament) show evidence that different regions determine different political forces, which usually confront each other. Cultural regional divides, and different geopolitical gravitations inherent to the west and east of the country, shall remain an important factor mobilising the electorate. Such polarisation will render the political competition full of tension and hostility. This impedes the possibility to conclude the political agreements and coalitions. Therefore political instability remains among the key features of political system in Ukraine.

\footnotetext{
${ }^{23}$ Николаенко Т., “Где Янукович потерял 300 тысяч, а Тимошенко получила 1,5 миллиона”, Украинская правда, http://www.pravda.com.ua/ru/news/2007/10/8/65005.htm, 08102007.
} 


\section{Political Parties as Parochial Political Players}

Most political scientists in the Ukraine are rather strict regarding the national political parties. It is often observed that the national political parties lack an ideological definition and form strictly disciplined and hierarchical political compounds. There is still significant role played by the personality of the leader and the distance between common part members and the party elite is still great. ${ }^{24}$ Even if we assume that some assumptions are not quite exact we would still have to agree with the others. Strict party discipline of political parties in Ukraine is clearly overestimated. Even big parties face certain inner schism (e.g. some influential party members recently deserted block by Tymoshenko and established party of liberal democrats. Confrontation in the Party of Regions between two most influential political groups and informal leaders, Yanukovych and businessman Akhmetov in this political organisation has drawn considerable attention in the press).

On the other hand, we would be inclined to think that observations on divides between party elite and common members or concerning the enclosure of party elite is of considerable significance. According to investigators, the party political career is more likely upon changing from one party to the other rather than inside the party. By the way, the 2007 political crisis between the President and the Rada occurred when group of deputies in opposition joined the parliamentary majority (such trends are also inherent to deputies of local elected authorities. Introduction of imperative mandate in case of local deputies should stop their movement). When a party member changes his party dependency, he is usually sure of his high ranking in the new party nomenclature. On the contrary, activity in primary party structures usually does not guarantee any political career perspective. ${ }^{25}$

Enclosure and tendency for oligarchy in political parties is determined by the fact that key role in the party is played by financial sponsors who control financial cash flows of the party. ${ }^{26}$ In case of party hierarchy, taking one step down, there are clients of key financier of the party; they, however, do not play independent political role. In general, unless an influential guardian or financial resources are available, the advancement in a political career is very complicated. Common party members are normally passive and are found at the bottom of the pyramid. ${ }^{27}$

Political programs or ideological provisions are fairly insignificant regarding the identification of the party. They are nothing but a screen covering a hierarchical and oligarchy character of parties. National political parties basi-

\footnotetext{
${ }^{24}$ Олещук П., “Политические партии современной Украины: между клановой системой и феодальным образованием”, Украинская правда, http://www.pravda.com.ua/ru/, 10102007.

${ }^{25}$ Ibid.

${ }^{26}$ See: Данилов А., “Коалиция “оранжевых” партий: террариум единомышленников”, http://www. ura-inform.com/archive/?/2006/02/15/ /60503, 15022006.

${ }^{27}$ Олещук (see footnote 21 )
} 
cally compete as to which shall offer its electors a more effective social economic program corresponding to their high expectations. True, often no care is taken as to the measures to implement such program. The 2007 Rada election serves as a good example in this respect. The Party of Regions positioned itself in terms of force able to ensure sound relations with Russia together with lower gas price for consumers whereas the block by Tymoshenko advocated the issue of active restoration of deposits.

To sum it up, one can claim that the key political parties in Ukraine rely on influential business supporters. Where economical interests of the latter do not coincide, the chances for the political party to reach for agreement and seek compromise decrease significantly. On the other hand, when the factor of political ideology in party identification further decreases, the factor of culture and region increases accordingly. The Party of Regions has traditionally identified itself in the Rada election by advocating the introduction of Russia in terms of the second official language and supporting the neutral status of the country (however, we shall still observe that neither 'orange' forces, nor the Party of Regions did emphasise the priorities in foreign policy during election campaign).

\section{Twists of Constitutional Reform or Back to the Presidentialism?}

Just to give one a short reminder, effective January 2006, constitutional reform entered in effect in Ukraine. It provided for an extension of the office of the Rada from 4 to 5 years. The reform increased the role of political parties in the political system; it concerns both local authority election as well as national ones performed on the basis of proportional system (introduction of imperative mandate was strongly advocated, meaning deputies elected on the basis of party list forfeit their mandate when changing from one political group to the other during their term in office). Political party or coalition of the same, scoring majority in the Parliament submits candidate to take the position of the Prime Minister to the President. The President has retained important powers: he is entitled to remove Parliament, where it fails to form Government within 60 days from the beginning of its work; the President shall have the prerogative to appoint foreign and defence ministers and shall be responsible for the foreign policy of the country. True, the President may no longer appoint members of the cabinet or recall the same unless permission by the Parliament is given beforehand. The President may no longer veto amendments of the constitution. On the other hand, the reform does not discuss the limits of competence of President and the Prime Minister, nor does it define the status of opposition in the Parliament. In other words, no rules were formalised as to the manner to deal with the conflicts between key branches of power: the President and the Legislative, the President and the Government, or guarantees of political forces while in opposition. 
In general, even those political analysts that have a strict attitude towards Ukraine were compelled to acknowledge that constitutional reform was responsible for considerable change in political, institutional system of the country as Ukraine renounced strong presidentialism, inherent to countries in the CIS area. ${ }^{28}$ Such changes were meant to be an important safety lock keeping the political system from authoritarianism. With the transfer of President's powers to the Prime Minister, the intensity and opposition of political competition regarding person to be elected President of the country was expected to decrease. The political system under formation was intended to be based on the balance between 'sufficiently strong President' and 'sufficiently strong Prime Minister'. At the same time, it was acknowledged that such system posed a certain risk that the country might experience permanent political crisis and instability where the President and the Prime Minister representing different political forces fail to reach compromise. The political process in Ukraine was further complicated by the absence of clear rules to settle the conflicts regarding two branches of the executive power in practise. On the other hand, we should keep in mind the fact that principles of constitutional reform were agreed under conditions of deep confrontation between the political elite and public groups supporting the same. It is therefore only natural that the most important and principal issues were left out. The relation between central and local powers was not clearly considered either. The constitution does not describe procedure on the way to appoint heads of local administrations. It says that the candidates shall be submitted by the Cabinet and approved by the President; however, it says nothing of the case where the President does not approve of the candidate. So the President can arguably delay the appointment of the head for considerable period of time, yet it may pose a risk to the efficiency of state governance. ${ }^{29}$ To sum it up, one can claim that political reform was compromise in nature which allowed for prevention of deep stage crisis in the late 2004 to the early 2005, but it did not discuss most issues of institutional character so vital to the state.

There is therefore little wonder that when the crisis ended, there appeared demands to review the constitutional reform or abandon it as a whole. Such demands were stated by the orange camp more often. It is fairly easy to explain the interest of the 'orange' to review the constitutional reform and to return to model of presidential republic. This is one of the ways for President Yushchenko to preserve prestige and political influence whereas his trust by the public was on the decrease (when Tymoshenko lost power, she no longer needed reform either). The opponents of the 'orange' ones rejected the arguments regarding review of constitutional reform and claimed that abandonment of political reform would raise issue of legitimacy of presidential election in Ukraine, i.e. the issue of legitimacy of Yushchenko. Just to remind ourselves,

\footnotetext{
28 “Чем грозит Украине партийный хаос, интервю директора Российского института стратегических исследований Е Кожохина", http://www.izvestia.ru/world/article3076313, 17022006. 29 “Эксперт: Необходим переход к новой стадии Конституционной реформы”, http://www. korespondent.net, 21112006.
} 
that both political parties, advocates of Yanukovych and Yushchenko, agreed upon the idea of repeated election as soon as political reform was agreed upon. Therefore as it is claimed reform alone took Yushchenko to be elected President in the country. ${ }^{30}$

When the Party of Regions formed the majority in the Rada and Yanukovych took the position as the Prime Minister, a battle, both visible and invisible as to who, the President or the Prime Minister will get more influence and power, got underway. Such a competitive fight had a negative effect upon state governance. The hostility between the two institutions of executive power reached their peak by the late 2006 to early 2007. The cornerstone for disagreement was the Law on Cabinet. By the way, this was the law that was in the process of consideration at least ten years. The passing of the same was basically blocked by Kuchma, former President of the country, as given absence of the law, the governance of the entire executive power was simply more expedient (when the tandem of Yushchenko and Tymoshenko entered in power, the Law on Cabinet was not adopted by autumn 2005 either). According to experts, a constitutional reform included provisions open to different interpretation. This was exactly what both branches of the executive power did, by interpreting given provisions to suit its interests. ${ }^{31}$ The ideas proposed by the entourage of the President regarding expansion of field of influence of National Security Council serve good example of such a 'competition' which could have made state governance even more complicated. This was in fact intent to balance out the increase of competence of the Cabinet. Surely, the conflicts of this kind should be dealt by the Constitutional Court. However, the same was not formed until the mid-2006 and therefore did not arbitrate the disputes between separate branches of the executive power.

Meanwhile the discussions regarding the constitutional reform gained intensity and zealousness. There appeared to be a trend where political parties, dominating political system would treat rules of constitutional reform in a different manner, even quite to the contrary. It has been observed that from the passing of Constitution in 1996 until 2004 in Ukraine, the constitutional ambiguities would be filled by the acts of the President. Whereas in the second half of 2006 until the early 2007 we saw disputes regarding the authority to fill the constitutional cavities gain increasing intensity. There appears to be 'systematic' competing on distribution of competence between different branches of power, primarily between the Prime Minister and the President. ${ }^{32}$ There was an undisputable conclusion drawn by the investigators in Ukraine, namely, that any effort to enhance and expand competence of any given institution of executive branch would do nothing but balance out readily unstable political system of the country. Therefore the idea by the President Yushchenko on the

\footnotetext{
${ }^{30}$ Мусияка В., “Судьи КС могут стать орудием антиконституционного переворота”, http://www. glavred.info, 06112006.

${ }^{31}$ Мусияка (see footnote 27)

${ }^{32}$ Рунак О., “Теория кожаной перчатки”, www.glavred.info, 05092006.
} 
formation of the constitutional committee to facilitate dealing with constitutional issues of different character in principle deserves positive evaluation. (There were hints by the President regarding formation of the above committee back in April 2006, and steps were taken to do son in November). True, no such dispute settlement mechanism could work unless there's a consensus between key political forces. Therefore those in favour of regionalism interpreted talks by the President on amendment in constitutional reform as nothing but efforts to abandon the reform altogether. ${ }^{33}$ (As a matter of fact, notions on abolishment of reform were increasingly louder by the end 2006. In December Our Ukraine drew an application to the Constitutional Court regarding allegedly illegitimacy of political reform). ${ }^{34}$

It likely that the reinstated Constitution, drawn upon initiative of the President and his entourage, will be 'pro-presidential'. One would have reason to believe that the discussions regarding contents of the Constitution will be yet another factor to polarise political elite in Ukraine as well as the society.

\section{Conclusion}

It is safe to claim that political instability will remain one of key features of political system in Ukraine. We believe political instability to be determined by several factors:

- First, cultural - regional divides, different geopolitical gravitations, inherent to the 'West' and the 'East' of the country, will remain an important factor to mobilise the electorate. It is due to this polarisation that the political competition will be increasingly tense and hostile. It also makes a political agreements and coalition less likely;

- Second, with the influence of political ideologies on identification of parties less significant, that of cultural - regional one increases. On the other hand, key political parties in Ukraine are still heavily dependant upon influential business, oligarchic, groups. Where economical interests of the latter do not coincide, the chances for political parties to reach for agreement and seek compromise to decrease significantly;

- Third, political, and constitutional, reform was meant to be an important safety lock keeping political system from authoritarianism. With the transfer of President's powers to the Prime Minister the intensity and opposition of political competition regarding person to be elected President of the country was expected to decrease. The political system under formation was intended to be based on the balance between 'sufficiently strong President' and 'sufficiently strong Prime Minister'. At the same, time it was acknowledged that such a system posed a

\footnotetext{
33 “Эксперт: Необходим переход к новой стадии Конституционной реформы”, http://www. korespondent.net, 21112006.

34 “Оппозиция взялась за отмену политреформы”, http://www.korespondent.net, 04122006.
} 
certain risk that the country might experience a permanent political crisis and instability where the President and Prime Minister representing different political forces failed to reach a compromise. The political process in Ukraine was further complicated by the absence of clear rules to settle the conflicts regarding two branches of the executive power in practise. To sum it up, it is safe to claim that political reform reminds a compromise which allowed prevention of deep political crises in the late 2004 to early 2005, yet did not deal with a variety of matters of a constitutional character having vital importance to the state.

\section{Bibliography}

1. Goldstone J., Ulfelder J., "How to Construct Stable Democracies" The Washington Quarterly, vol. 28, Winter 2004/2005.

2. Konieczna J., "Mędzy Wschodem i Zachodem”, Fundacja Batoriego, Warszawa, 2004.

3. Moshes A., "Ukraine: Domestic Changes and Foreign Policy Reconfiguration", Political Trends in the Eastern Europe: Ukraine and Belarus (ed. by V. Silitski and A. Moshes), 2007. www.StrategicStudiesInstitute.army.mil.

4. Pigenko V., Wise Ch., Brown T. L., "Elite Attitudes and Democratic Stability: Analysing Legislators' Attitudes towards the Separation of Powers in Ukraine", Europe - Asia Studies, vol. 54, no. 1, 2002.

5. Šatūnienė Ž., "Nepastovus posovietinès Ukrainos politinis režimas ir demokratijos konsolidavimo perspektyvos", Politologija, nr. 1, 2006.

6. "Ukraine's European Integration in Popular Perceptions", National Security and Defence, no. 7, 2005.

7. "Will democracy survive in Ukraine? What the experts say", http://www.icps.com.ua, 20070212.

8. Ведерникова И., “Кабмин в законе”, http://www.zerkalo-nedeli.com/op/ show/612/54393/, no. 33, 200609 02-08.

9. Данилов А., “Коалиция “оранжевых” партий: террариум единомышленников”, http://www.ura-inform.com/archive/?/2006/02/15/ /60503, 20060215.

10. “Доклад Института национальной стратегии Украины (С. Белковский, К. Бондаренко, В. Вакарюк, Е. Курмашов, А. Мушак). Новый политический сезон: выборы-2006 и продолжение оранжевой революции", Агентство политических новостей, http://www.apn.ru, 20050824.

11. “Евгений Головаха: “Борбу между “правыми” и “левыми” некомпетентные политики превратили в войну между региональными и языковыми групами”, http://www.grani.kiev.ua, 20060806.

12. Мусияка В., “Судьи КС могут стать орудием антиконституционного переворота”, http://www.glavred.info, 20061106. 
13. Николаенко Т., "Где Янукович потерял 300 тысяч, а Тимошенко получила 1,5 миллиона", Украинская правда, http://www.pravda.com.ua/ru/ news/2007/10/8/65005.htm, 20071008.

14. Олещук П., "Политические партии современной Украины: между клановой системой и феодальным образованием”, Украинская правда, http://www.pravda. com.ua/ru/, 20071010.

15. “Оппозиция взялась за отмену политреформы”, http://www.korespondent.net, 20061204.

16. “Почти половина украйнцев щитает, что при Ющенко они стали жить хуже”, www.rosbalt.ru, 20051020.

17. Рунак О., “Теория кожаной перчатки”, www.glavred.info, 20060905.

18. “Чем грозит Украине партийный хаос, интервю директора Российского института стратегических исследований Е Кожохина”, http://www.izvestia. ru/world/article3076313, 20060217.

19. “Эксперт: Необходим переход к новой стадии Конституционной реформы”, http://www.korespondent.net, 20061121.

20. “Эксперты: “Оранжевые” министры не сработаются с Януковичем”, www.Korrespondent.net, 20060822.

21. Якименко Ю., Литвиненко А., Жданов И., “Кто и за что, с кем и против кого? Партии Украины за год до выборов”, http://www.zn.ua, 20050402. 